\title{
JIT 生産システムの特質と方法
}

由 井 浩*

\section{最近の技術}

\section{1. はじめに}

近年，我国製造業の国際競争力が強くなり，大幅 な貿易黒字を計上してきた。これに関連して日本企 業の生産システムが海外から関心を集めている ${ }^{1,21}$.

トヨ夕生産方式 ${ }^{3)}$, ストックレス生産 ${ }^{4)}$ な゙日本の 企業が開発した生産システムは, 今日国の内外で「ジ ヤストインタイム (JIT) 生産システム」と総称さ れるようになった。本稿は, 生産システムの発展を 素描し, JIT 生産システムの考え方及びストックレ ス生産のすすめ方などを検討する.

\section{2. 生産システムとその発展}

JIT 生産システムを取上げるに先立って, 生産シ ステムの概要をみておくことにする.

\section{1 生産システムの概念}

長谷川占によれば，生産システムは図 1 のように， (1)変換システムと(2)管理システムとから構成され る.このうち(1)は，原材料を製品に変換することに 直接関係する人々や機械設備によって構成される， 物的システムあるいは作業システムである。(2)は変 換の場を管理する人事管理・設備管理などのシステ ムと, 変換される対象を管理する日程管理・品質管 理などのシステムから成り立っている.

次に Garretと Silver ${ }^{6)}$ は，より広義に解し，製品 設計や資金計画なども生産システムに含めている

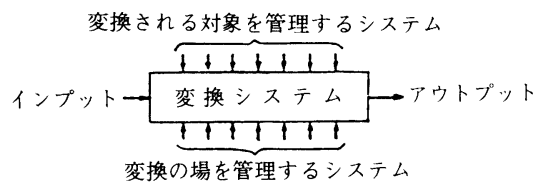

図 1 生産システムの構造図 5
(図 2).このように我々が生産システムというと き, それには生産手段のみならず生産対象や管理の 問題も含まれるのである.

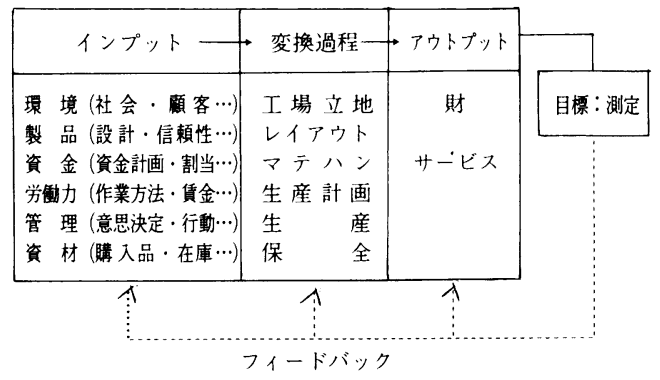

図 2 生産システム

\section{2 生産システムの発展}

上記のような生産システムは，18世紀後半のイギ リスにおける産業革命による工場制度の確立ととも に萠芽した。すなわち，機械制工場生産への移行と， それに伴う管理方式の変革である7. それ以降の生 産システム全般の発展を取上げる余裕はないので, ここではごく簡単にみておくことにする.

村松 ${ }^{8)}$ は, 企業がその時々に当面した問題を解決 するために開発した生産システムに関して，フォー ドの流れ作業方式（1917年）以降を表 1 のように要 約している.フォードシステムは䪊的な低コスト と短生産期間を同時に実現した。フォード $\mathrm{T}$ 型の シェアは1909年の $9.38 \%$ から1921年には55.45\%へ と上昇し，他社を圧倒した。このことを可能にした のは，単一製品・多量生産であったからである。し かし, 消費者ニーズをとらえた GM は, 複数の車 種・年々のモデルチェンジなどによって1927年にフ オードを抜き, 以後今日まで自動車販売高の第 1 位 を不動のものにしている. フォード対 GMのケー 
表 1 各種生産方式と特徵

\begin{tabular}{|c|c|c|}
\hline 方 式 & 年代 & 特 \\
\hline $\begin{array}{l}\text { フォードの } \\
\text { 流れ作業 }\end{array}$ & 1917 & $3 \mathrm{~S}\left(\begin{array}{c}\text { 標準化 } \\
\text { 専門化 } \\
\text { 単純化 }\end{array}\right)$ と $3 \mathrm{M}\left(\begin{array}{c}\text { 大量消費 } \\
\text { 大量販売 } \\
\text { 大量生産 }\end{array}\right)$ \\
\hline $\begin{array}{llll}P & E & R & T \\
C & P & M\end{array}$ & 1955 & 個別生産の大型プロジェクトの管理 \\
\hline $\begin{array}{l}\text { フォードの } \\
\text { 混合ライン }\end{array}$ & 1962 & 多品種で需要変動に対処 \\
\hline $\begin{array}{l}\text { Volvo方式 } \\
\text { カルマ }\end{array}$ & 1970 & アブセンティズムと環境改善 \\
\hline MRP方式 & 1970 & $\begin{array}{l}\text { 複雑な部品構成の生産で変動への対処を押 } \\
\text { 出し方式とコンピュー夕管理 }\end{array}$ \\
\hline トヨ夕方式 & 1970 & $\begin{array}{l}\text { 複雑な部品構成の生産で変動への対処を引 } \\
\text { 取り方式と自己調整と改善 }\end{array}$ \\
\hline $\mathrm{F} \quad \mathrm{M} \quad \mathrm{S}$ & 1977 & $\begin{array}{l}\text { 多品種の部品加工を段取·移動時間最少に, } \\
\text { かつ自動化する }\end{array}$ \\
\hline $\begin{array}{l}\text { 新日鉄ナゴ } \\
\text { ヤ生産方式 }\end{array}$ & 1977 & $\begin{array}{l}\text { 装置工業で流れの異なる多品種注文を多目 } \\
\text { 評価のもとに生産するシミュレータを用い } \\
\text { た }\end{array}$ \\
\hline
\end{tabular}

（村松林太郎，I Eレビュー，1982・№.4）

スは多品種化が不可避なことを示している.

ところで, 生産の目的を平易にいえば, 必要な (多 品種の) ものを, 早く, 安く作ることである. 生産 は図 3 のように「作業」と「工程」の網目構造にな っている．作業の立場では，できるだけ量をまとめ て各工程における加工費を下げようとする。一方, 工程の立場からは, ロットを小さくして生産期間を 短縮しょうとする．この両者は一般には二律背反の

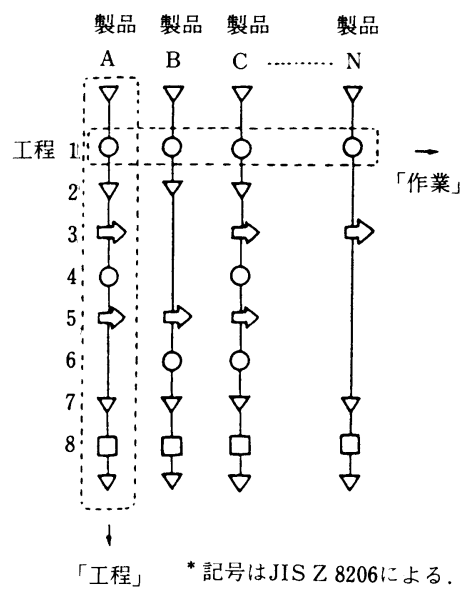

図 3 「工程」と「作業」の網目構造
関係にあるが，フォード以後の生産システムは生産 設備の進歩を中心にして低コストを追求してきたと いえよう.すなわち，作業重視の立場である．表 1 におけるトヨタ方式は「ポストフォードの低加工費 志向を崩すことなく，その上にフォードシステムの 流動化 (=短生産期間) 原理を﨡らせたのである ${ }^{91} 」$. このトヨタ生産方式は, ジャストインタイムと自動 化を 2 本柱として成立つが，最近では前者が同生産 方式を表す言葉としてよく使われるようになってき ている、なお，略語の “JIT"を言い始めたのは Schonberger ${ }^{10}$ である.

\subsection{JIT と経営成果}

周知のように資本利益率は経営成果の測定に際し て, 最重視される指標である，それは売上高利益率 と資本回転率の積であり,

$$
\text { 資本利益率 }=\frac{\text { 利 益 }}{\text { 売上高 }} \times \frac{\text { 売上高 }}{\text { 資 本 }}
$$

で表される. 従って, 利益の増大（=低コスト）と 回転のスピード化（=生産期間の短縮）が資本利益 率を高めることになる．前節でみたように，トヨ夕 生産方式が喧伝されるまでは生産システムは低コス 
トに重点が置かれた。

\subsection{1 高度成長と生産システム}

日本の経済成長は，諸外国と比べてみたとき，ま ことに驚異的であった。この高度成長を支えた要因 として, 社会的・経済的・技術・地理など様々な性 質のものを考えることができる ${ }^{11}$. それらのうち， ここでは技術革新と管理技術の 2 つを取上げてみよ う.

1960年代に日本の労働生産性は年率 $11.1 \%$ も昇 した。この主因は設備投資を中心とした技術進歩で ある. 同時に, 多くの管理技術の導入がコストダウ ンを推進した。これら 2 つの要因は, 先の(1)式との 関連でいえば, どちらも低コスト，すなわち生産に おけるポストフォードの立場の追求にその重点があ ったといえよう。

\subsection{2 管理の尺度としての回転率}

工場の場合,

資本の回転期間 $=$ 購入期間 + 製造期間 + 販売期間 + 与信期間

である，資本回転に関して生産が主として関与する のは，原材料の在庫期間と製品の生産期間である.

これらの回転を早くするため生産管理が実施され る.つまり, 材料や仕掛品の回転率は生産管理の優 劣の尺度とみることができる．このうち，仕掛品の 回転率は次式で表される。

$$
\begin{aligned}
\text { 仕掛品回転率 }= & \{(\text { 製造原価 }+ \text { 材料費 }) \div 2\} \\
& \div \text { 仕掛品在高 }
\end{aligned}
$$

又,

生産期間 $=360 \div$ 仕掛品回転率（日）

である。このように仕掛品を中心とした在庫の削減 は資本の回転を早める。ポストフォードの生産シス テムが(1)式の右辺第 1 項（=低コスト）を追求した のに対し, JIT 生産システムは右辺の第 1 項と第 2 項を同時に向上しょうとするものであるということ ができよう。

\section{3.トヨタ生産方式, ストックレス生産, JIT 生産システム}

\section{1 トヨタ生産方式 ${ }^{12}$}

本生産方式の主要目的は, コストの低減と資本回 転率の增大により会社全体の生産性を向上させるこ とである.このためには次の副次目標が同時に達成 される必要がある。

(1) 量と種類の両面にわたる日次ならびに月次の
需要変動に適応しうるような数量管理

（2）各工程が後工程に良品だけを供給しうるよう な品質保証

（3）コスト低減目標を達成するために人的資源を 利用する限りは，同時に人間性の尊重が高めら れなければならないこと

図 4 は上記のような目標と達成手段の関係を表し ている.

\subsection{1 トヨタ生産方式の主要コンセプト}

必要なものを, 必要な時に, 必要な量だけ作るこ とを意味するジャストインタイムと，不良品を前工 程から後工程に流さないようにする自働化, この 2 つの概念がトヨ夕生産方式の 2 本柱である，さらに 加うるに需要の変化に対応して作業者数を弾力的に 変化させる「劣人化」と，作業者の提案を通じて改

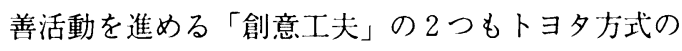
重要な概念であるとされている.

\section{1 .2 目標実現のための手段}

上記 4 つの概念を実現するため, 以下の方式と手 段が構じられる.

(1) カンバン方式

(2) 生産の平準化方式

(3) 段取り替え時間の短縮

(4) 作業の標準化

(5) 機械レイアウトと多能工 (作業員数の弾力化)

(6) 改善活動と提案制度

(7) 目で見る管理方式

(8) 機能別管理方式

\subsection{3 トヨタ方式による成果}

表 2 はトヨ夕方式を採用した企業のうち，Bクラ スの成果を示したものである. 採用及び実施の方 法・内容の違いはあろうが, Bクラスの企業におい ても相当の成果を納めていることがわかる ${ }^{13}$. 熊谷 教授（名工大）はトヨ夕方式が低加工費と流動化原 理の双方を実現させたとして, 生産管理史上に世界 的な位置づけをしている ${ }^{14}$. しかし，一方，この方 式に対して国会における議論や, 公正取引委員会の 指摘など, 種々の批判も行われた(i注1).

\section{2 ストックレス生産}

ストックレス生産という名称は, 関西経営システ 么協会 (Kansai Institute of Management \& Systems Engineering: KIMS）の第 1 次 IE 応用研究会（昭和 53年 7 月～-54年 10 月，主查 福田龍二）によって案 出されたものである，ストックレス生産は「必要な ものが, 必要な時に, 必要なだけ作られること」を 理想とし，そのために行う計画や統制・諸改善, 現 


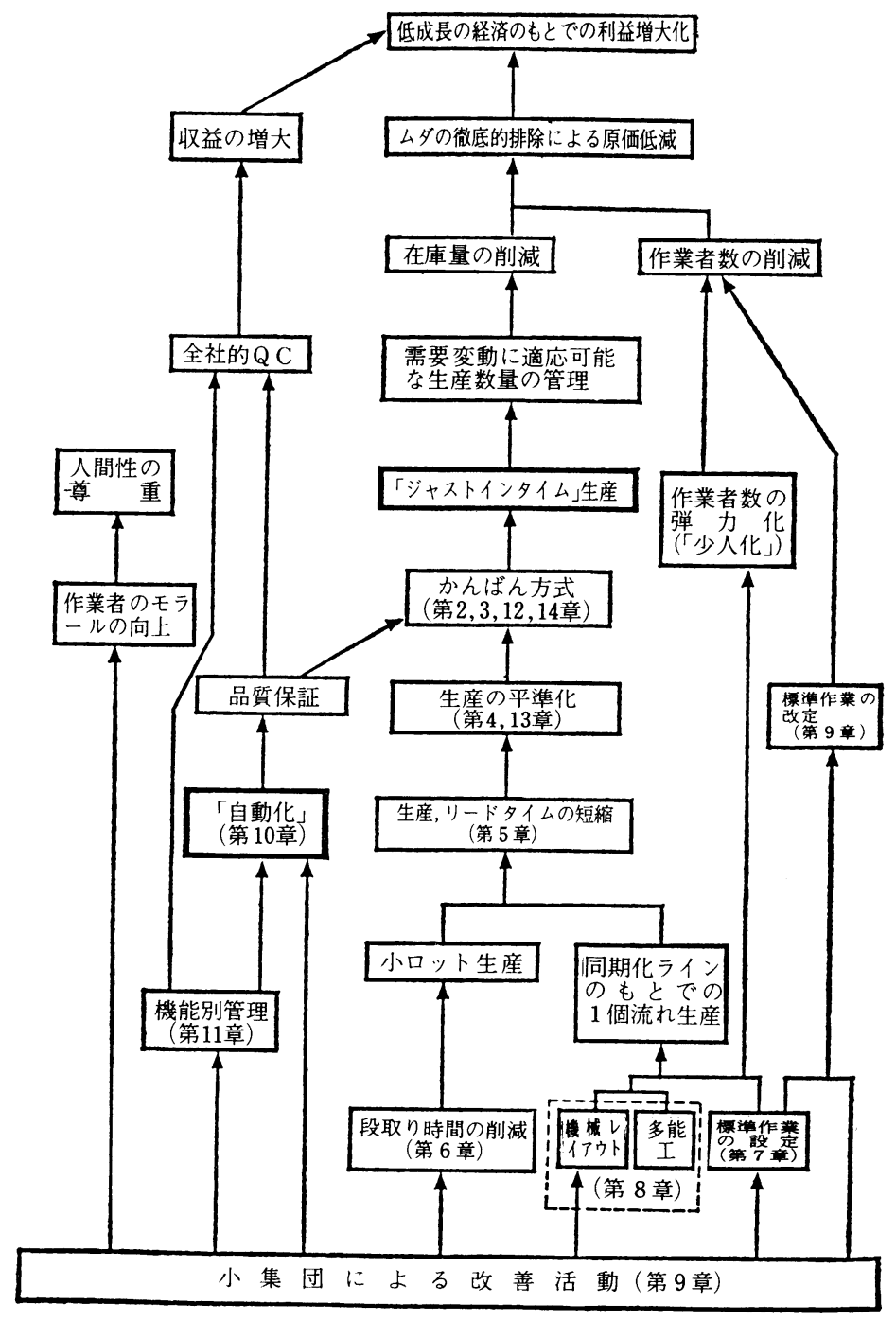

図 4 トヨ夕生産方式の体系：コスト・数量・品 質・人間性とその諸手段の関係（門田 3 よ り)

表 2 トヨ夕方式採用による成果例

\begin{tabular}{c|c|c|c|c}
\hline \hline 企業 & 期間 & $\begin{array}{c}\text { 在 庫 削 減 } \\
\text { (改善前比) }\end{array}$ & $\begin{array}{c}\text { 生産期間短縮 } \\
\text { (改善前比) }\end{array}$ & $\begin{array}{c}\text { 労 働生産性 } \\
\text { (向 上 率) }\end{array}$ \\
\hline $\mathrm{A}$ & 3 年 & $45 \%$ & $40 \%$ & $50 \%$ \\
\hline $\mathrm{B}$ & 3 & 16 & 20 & 80 \\
\hline $\mathrm{C}$ & 4 & 30 & 25 & 60 \\
\hline $\mathrm{D}$ & 2 & 20 & 50 & 50 \\
\hline
\end{tabular}


20

場での活動全般を総称して呼んだものである.

ストックレス生産システムでは, 目的達成のため に8つの方法論と, 諸改善の推進，パソコンによる 支援システムなどを準備している．しかし，このシ ステムの導入に際しては画一的な方法をとらない. 各企業, 工場の個有の状況を重視し,「ストックレ 不生産は個性的」という立場を強調している．前述 のIE 応用研究会は現在も継続されている.

\subsection{JIT 生産システム}

Hall, R. W. は著書 Zero Inventries（1983）のなか で前節の KIMS とは全く独立に, 偶然にもストック レス生産という語を使った，同書はトヨ夕生産方式 を考察するとともに，さらに製品設計・製造戦略に も敷衍している，ところが現在では，国内扔よび海 外においても, トヨ夕生産方式, ストックレス生産 システムなどの総称としてジャストインタム生産シ ステムという語が用いられることが多くなってい る(泣2).

\section{4.ストックレス生産システム}

本章では，今日 JIT 生産システムと総称されるも ののうち，筆者が参加させていただいた前述の IE 応用研究会の開発になるストックレス生産をやや詳 しくみてみよう ${ }^{15.16)}$.

\section{1 ストックレス生産のねらい}

仕掛品を減少し，生産期間を短縮することにより 次の成果を期待することができる.

（1）ストックを圧縮することにより，生産上の諸 問題及び弱点を顕在化させる（図 5 ）.

(2) 生産管理に起因するむだの排除と生産管理コ ストの削減をする

(3) 需要の変動への対応力の向上が可能になる

(4) 小ロット化, 短納期化に応じて納期体質の改 善ができる

\section{2 ストックレス生産のすすめ方}

（1）達成目標の決定

ストックレス生産の達成目標は, 生産部門の責任 者が設定する，在庫量，ロットサイズ，能率など多
緎維 機 械学会 誌

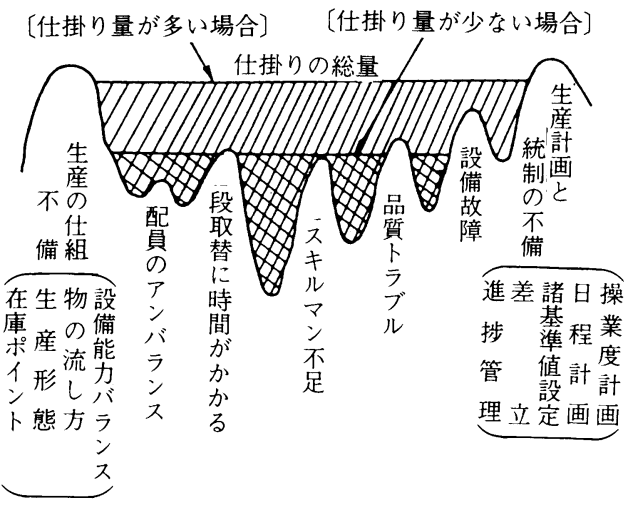

図 5 仕掛りの量と生産上の問題点

くの項目が考えられるが，総合的には納期管理体質 指標（DC 値）とフロー指標（F 值）を用いる.

$\mathrm{DC}$ 值 $=\frac{(\text { 納期達成評点 }) \times(\text { 納期管理評点 })}{100}$

$$
\left(\begin{array}{l}
\text { 納期達成評点 }=100-\mathrm{P} \\
\text { ここで, } \quad \mathrm{P} \text { は期遅れ率（\%) であり， } \\
\mathrm{P}=\frac{\text { 納期遅れ件数 }}{\text { 納入件数 }} \times 100
\end{array}\right)
$$

又,

$$
\left(\begin{array}{c}
\text { 納期管理評点 }=100-\frac{\sum \mid \text { 実際納入日 }- \text { 約束納期 } \mid}{\text { 納入件数 }} \\
\times \frac{100}{\text { 級の幅 } \times \text { 片側の級の数 }}
\end{array}\right)
$$

なお，図 6,7 及び表 3 を参照されたい.

$$
\mathrm{F}=\frac{\mathrm{S}}{\mathrm{T}}=\frac{\text { 素材投入から完成までの平均生産期間 }}{\text { 素材投入から完成までの正味加工時間 }}
$$

$\mathrm{F}$ 值が100というのは, 正味加工時間 1 に対し, 停滞時間が99であることを示す.

(2) 全員参加の工程管理を目指す.

(3) 先ず仕掛量を減らしにかかる，そのため，現 状での各工程ごとの許容仕掛量の基準を定め, 仕掛 量を減らしていく，その基準はさらに減少させてい $<$.

（4）品種別ライン化と小ロット生産への切り替え を行う.

（5）日程計画立案のサイクルを短縮すると共に，

(注 1) 門田教授は『トヨタシステム』初版において,このような批判に対する本格的な考察は次回以降の版で行うことになろうと述 べている，同生産方式に対する評価・考察を行うには多面的・総合的な検討が必要であり，筆者自身のこの作業は他日に期す ことにする

(注 2 ) 例えば，今年 8 月に米国のシンシナティ大学で開催された第 9 回 International Conference on Production Research のなかでも 「Just-In-Time 方法論」のセッションが設けられた. 又, Harvard Business Review, 1986年 $3 / 4$ 月号に“JIT 導入をこばむ 7 つのいいわけ”という Walleigh. R. C.の論文が揭載されている. 


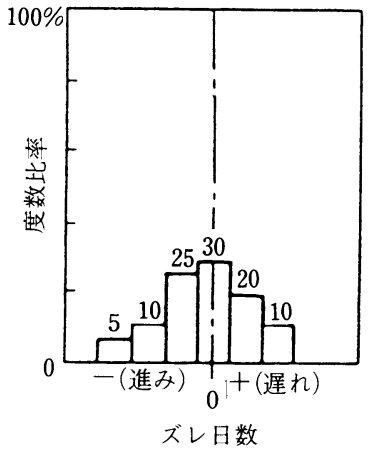

四 6 G工場の納期進遅ヒストグラム

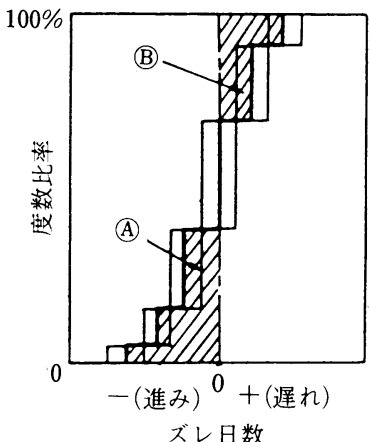

図 7 G工場の納期進遅累積曲線
目で見る生産管理板・現品管理によるコントロール を行う。

(6) 諸改善の推進

段取替時間の短縮，多能工化をはかり，機動的な 生産ができるようにする.

（7）評価（前述の DC 值， $\mathrm{F}$ 値）

以上の手段の相互関連は図 8 のように示すことが できる.

\section{3 ストックレス生産の推進日程}

ストックレス生産では画一的な進め方は考えない が，モデルとして図 9 と図10を示しておこう.

\section{4 ストックレス生産の効果}

ストックレス生産の効果をみるとき，導入方針， 組織, 活動内容, 日程などを併せみる必要があるが, ここでは数社の実施効果のみを示すにとどめる（表 $4)$.

\section{5. おわりに}

本稿ではトヨ夕生産方式, ストックレス生産など, 日本企業が開発した生産システムが，今日 JIT 生産 システムと総称され，国の内外で実施され，又，関

表 3 判定基準の一例

\begin{tabular}{c|c||ll}
\hline \hline ランク & 点 数 & \multicolumn{1}{|c}{ 判 } & \multicolumn{1}{l}{ 定 } \\
\hline $\mathrm{A}$ & 80 - 100 & 良 好 \\
\hline $\mathrm{B}$ & $60 \sim 79$ & かなりうまく管理されているが, もう一歩 \\
\hline $\mathrm{C}$ & $40 \sim 59$ & 管理意識はあるが, 統制面や生産能力面に不備あり \\
\hline $\mathrm{D}$ & $20 \sim 39$ & 管理もしている品物もある, という程度 \\
\hline $\mathrm{E}$ & $0 \sim 19$ & 無管理状態 \\
\hline
\end{tabular}

表 4 ストックレス生産の効果例

\begin{tabular}{c|c|c|c}
\hline \hline 企業 & 仕掛量 & 納 期 & 能率(改善前比) \\
\hline $\mathrm{D}$ 社 & 12 日分 $\rightarrow 6$ 日分 & $\begin{array}{c}\text { 遅 延 件 数 } \\
9 \% \rightarrow 2 \%\end{array}$ & $168 \%$ \\
\hline $\mathrm{N}$ & & $50 \%$ 短 縮 & $156 \%$ \\
\hline $\mathrm{S}$ & $56 \%$ 減 少 & 4.5 日 $\rightarrow 2.5$ 日 & \\
\hline $\mathrm{K}$ & $60 \%$ 減 少 & $43 \%$ 短 & $181 \%$ \\
\hline
\end{tabular}




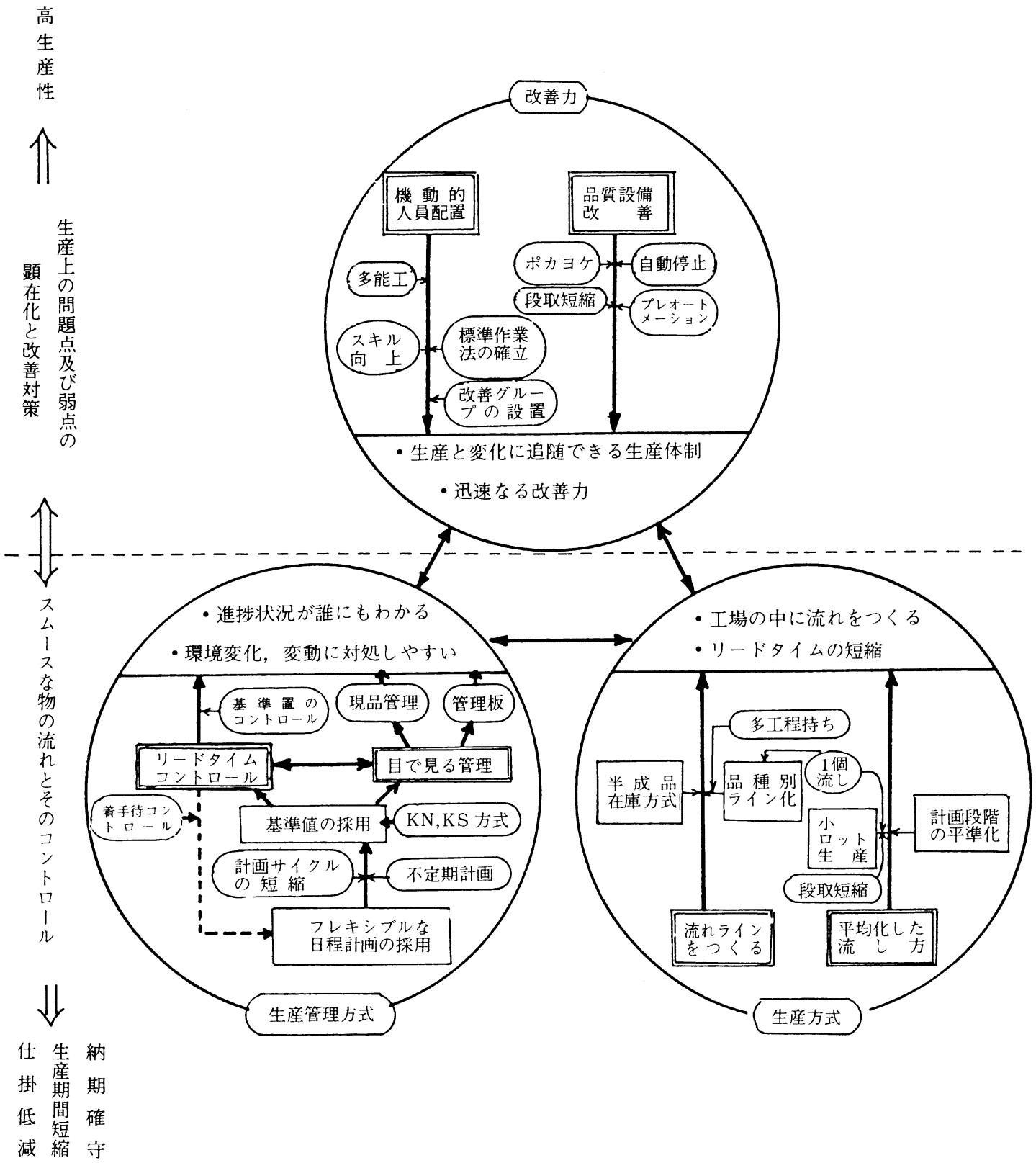

図 8 ストックレス生産達成手段の相互関連図

心を集めていることをみた。企業は環境に適応した 全社戦略，さらに競争戦略を定めて，業界での競争 優位を得ようとする。ささらそれら各戦略に，下位 レベルの機能別戦略が適合している必要がある. JIT 生産システムや TQC を企業がどのように位置 づけるかは, 機能別戦略の一部である生産戦略の構 成要素である，今後，JIT 生産システムの導入，展 開に際して，生産戦略の検討が重要になるであろ $j^{17)}$.

\section{参考文献}

1) Hall, R. W.: Zero Inventories, Dow Jones-Irwin (1983).

2) Schonberger; R. J., Japanese Manufacturing Techniques, The Free Press (1982)

3）門田安弘：「トヨタシステム」, 講談社 (1985)

4）関西経営システム協会,「ストレックス生産」, 日刊工業 新聞社（1986）

5）長谷川幸生;「多品種少量生産システム」, 日刊工業新聞社 (1970)

6) Garret, L. J. and Silver. M., Production Management Analy. sis, Harcourt Brace Jovanovich, Inc., (1973)

7）木村達二稿；「生産管理ゼミナール」, 古川, 高宮編, 「生 産管理の理論と方式」, 有斐閣 (1964) 


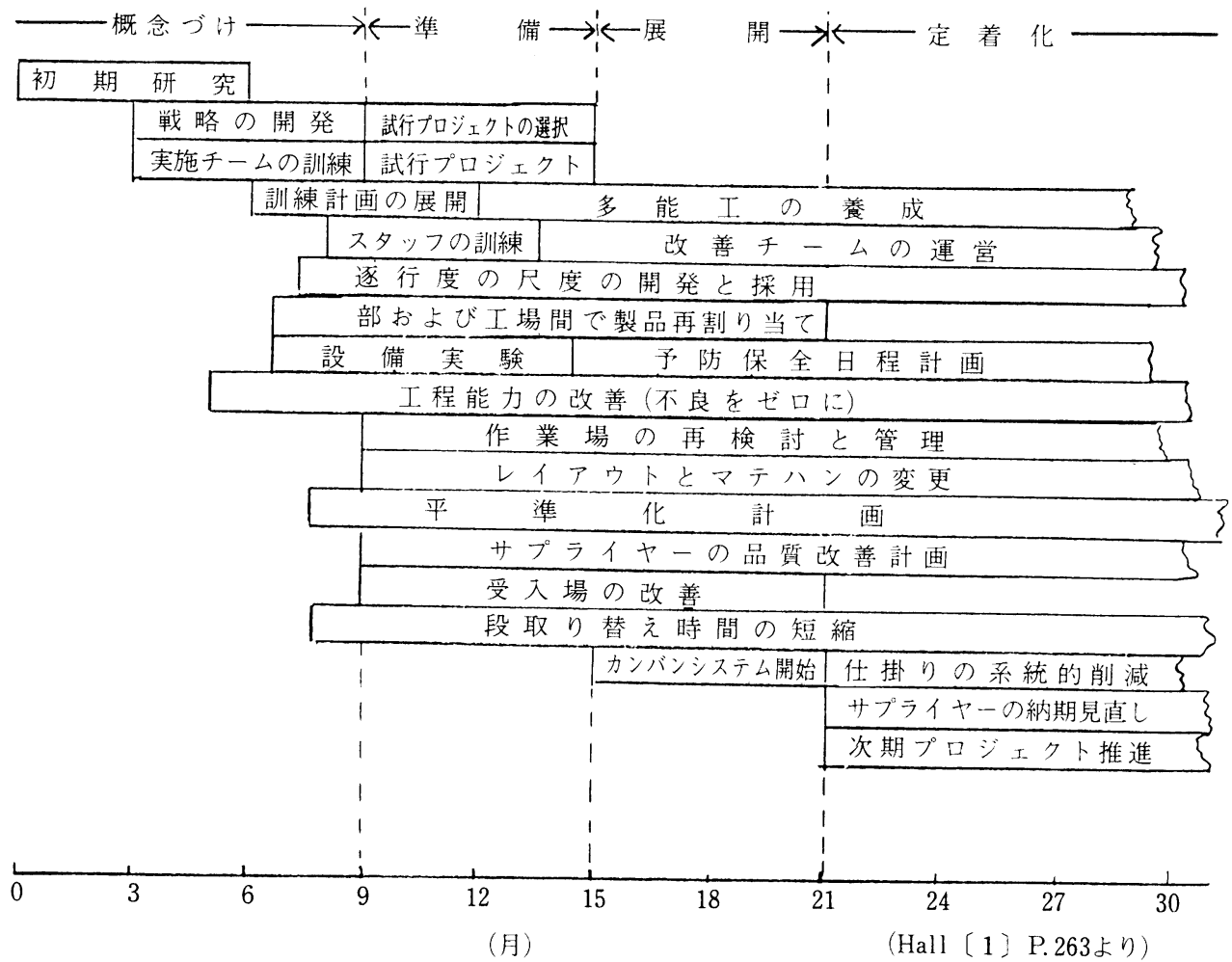

図 9 ストックレス生産の実施スケジュール (試案)

(本図は, 検討を始めるための簡素化したスケジュール案である. 何をなすべきかは, 各ケースや予見できない問題の性質に応じて決めるべきである)

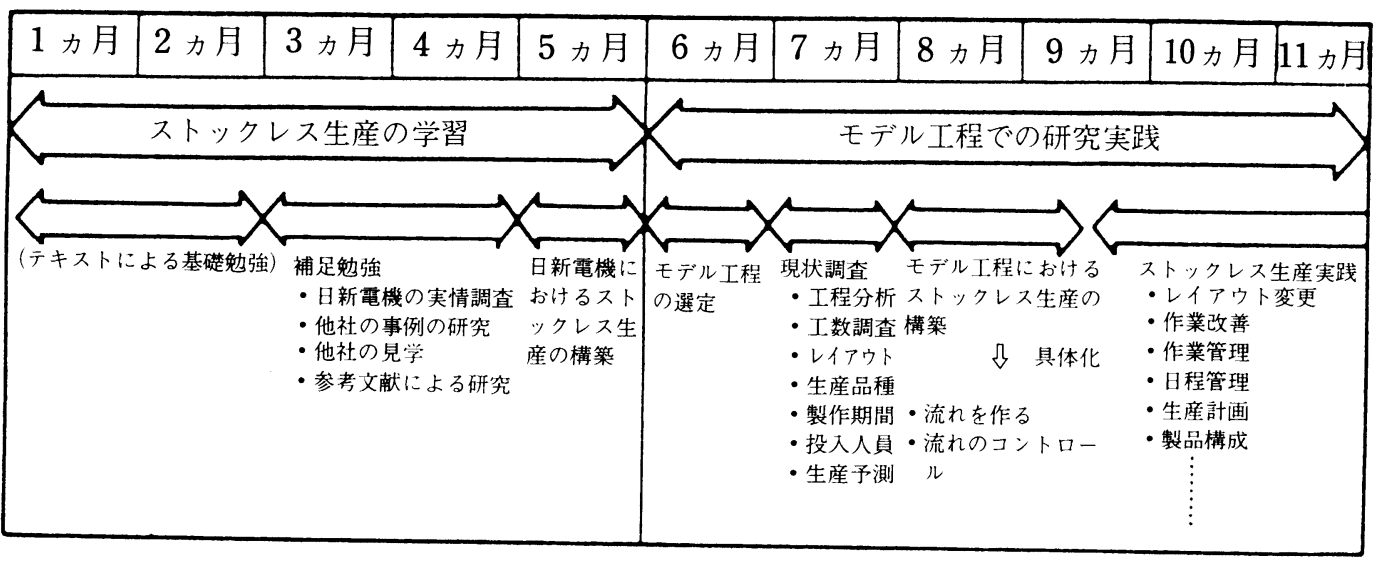

図10 ストックレス生産研究会活動計画（日新電機の例16より）

8）村松林太郎；欧米にみる工場マネジメントとトヨ夕生産 方式,「IEレビュー」, Vol.22, No.4, 155-163 (1982)

9）熊谷智德；WILL 9 月号, 166 (1985)

10) op. cit. (2), 17

11）林直道;「現代の日本経済」, 青木書店, 68（1976）

12) 前掲書 (3)

13) op. cit. (1), 24
14）熊谷智德：前掲 $(9)$

15）関西経営システム協会,「ストックレス生産」, 関西経営 システム協会 (1980)

16）前掲書 (4)

17) 由井浩; 生産戦略分析フレームワークの拡張,「日本経営 工学会春季大会予稿集」, (1987) 